\title{
Effects of message appeal and service type in CSR communication strategies*
}

\author{
Luisa Andreu, University of Valencia \\ Ana B. Casado-Díaz, University of Alicante \\ Anna S. Mattila, Pennsylvania State University
}

Puede citar este artículo como:

Andreu, L., Casado-Díaz, A.B. y Mattila, A.S. (2015), "Effects of message appeal and service type in CSR communication strategies". Journal of Business Research. Vol. 68, no 7, pp. 1488-1495. DOI 10.1016/j.jbusres.2015.01.039.

* The authors are grateful to Suzanne Beckmann (Copenhagen Business School), Alan Pomering (University of Wollongong), and Valèrie Swaen (Catholic University of Louvain) for comments on an earlier draft of this manuscript. Send correspondence to: Luisa Andreu, Department of Marketing, University of Valencia, Av. Naranjos, 46022 Valencia, Spain (luisa.andreu@uv.es); Ana B. Casado-Díaz, Department of Marketing, University of Alicante, P.O. Box 99, E-03080 Alicante, Spain (ana.casado@ua.es); Anna S. Mattila, School of Hospitality Management, Pennsylvania State University, USA (asm6@psu.edu). 


\begin{abstract}
Studies highlight the importance of corporate social responsibility (CSR) for companies' stakeholders. Consumers, however, are often unaware of such initiatives. Understanding how to effectively communicate socially responsible initiatives is an important challenge for both researchers and managers, who invest considerable resources in CSR initiatives. This study examines consumers' responses to two types of CSR initiatives (environment-related and employee-based) using two types of message appeals (emotional and rational) across two service types (hedonic and utilitarian). Consumers' responses provide data on their awareness of CSR initiatives, attitude toward the company, perceived firm uniqueness, emotional response, and attributions of company motives to engage in CSR activities. Rational appeals more effectively communicate environment-related CSR initiatives, whereas emotional appeals more effectively communicate employee-based CSR initiatives. Effects on consumers' attributions of company motives to engage in CSR are significant in both service types. Finally, rational message appeals affect consumers' CSR awareness and emotional responses, but only in utilitarian service.
\end{abstract}

Keywords: Corporate social responsibility; hedonic and utilitarian services; message appeal; website communication 


\section{Introduction}

Corporate social responsibility (CSR) is important in today's socially conscious market environment (Korschun et al., 2014). In marketing, CSR is the "management of stakeholder concern for responsible and irresponsible acts related to environmental, ethical and social phenomena in a way that creates corporate benefit" (Vaaland et al., 2008, p. 931). Studies show the importance of CSR for companies' stakeholders (Aguinis \& Glavas, 2012; Campbell, 2007). Consumers, in contrast, display a lack of awareness of socially responsible initiatives (Bhattacharya \& Sen, 2004; Öberseder et al., 2013; Sen et al., 2006). Understanding how to effectively communicate CSR initiatives is important to raise consumer awareness of CSR initiatives and develop brand equity (Beckmann, 2007; Hoeffler \& Keller, 2002; Hur et al., 2014).

Despite its importance, CSR receives scant attention in the literature (Pomering \& Dolnicar, 2009). Researchers are now calling for greater consumer and employee awareness of CSR initiatives (Korschun et al., 2014). This study therefore investigates the joint effect of CSR initiative type (environment-related or employee-based) and message appeal type (rational or emotional) on consumers' reactions to CSR initiatives across two service types (hedonic and utilitarian). This study contributes to the literature by analyzing how CSR communication strategies enhance CSR consumers' reactions to CSR initiatives. The study analyzes not only CSR awareness, but also CSR brand equity. The empirical research employs a 2 (type of CSRservice based initiative) $\times 2$ (emotional/rational message appeal) $\times 2$ (hedonic/utilitarian service) experimental design. Company websites act as stimuli platforms to communicate CSR initiatives. The choice of company websites as the CSR communication channel reflects their key role as an advertising and marketing channel (Argyriou et al., 2006; Bartl et al., 2013).

\section{Conceptual framework and hypotheses}

\subsection{Service-based CSR initiatives}

Although companies engage in a wide range of CSR initiatives (Bhattacharya \& Sen, 2004), this study focuses on two types: employee-based initiatives and environment-related initiatives. Both are relevant for services marketing (Zeithaml et al., 2013), and in this research they therefore receive the name service-based CSR initiatives.

Employee-based CSR initiatives include employee support (e.g., concern for safety and job security) and diversity (e.g., gender, ethnicity, and disabilities). Environment-related initiatives refer to activities such as recycling, use of environmentally friendly products, hazardous-waste management, and pollution control (Grimmer \& Bingham, 2013). Both types of CSR initiatives (i.e., employee-based and environment-related) can positively affect brand image (Bhattacharya \& Sen, 2004). 


\subsection{Emotional and rational appeals in CSR communication}

The advertising literature shows that message appeal design (i.e., emotional versus rational) is a primary strategic consideration (Singh \& Dalal, 1999; Stafford, 2005). Rational advertising assumes that consumers make rational decisions. Rational advertising's goal is thereby to change consumers' beliefs about a brand using arguments or reason (Albers-Miller \& Stafford, 1999). Rational appeals present facts straightforwardly and objectively (Stafford \& Day, 1995). In contrast, emotional appeals target the emotional or experiential facet of consumption. Such appeals seek to make the consumer feel good about the product, by creating a likeable or friendly brand (Albers-Miller \& Stafford, 1999).

Evidence as to the effectiveness of emotional and rational appeals is conflicting (Page et al., 1990). Using their elaboration likelihood model (ELM), Petty and Cacioppo (1984) find that rational appeals are effective when elaboration (i.e., the amount a person thinks about a message) is high, whereas emotional appeals are effective when elaboration is low. Um (2008) shows that elaboration is higher when the argument is relevant to the individual (i.e., high involvement), and lower when the argument is irrelevant. Persuasion literature implies that when CSR communication focuses on employee-based CSR initiatives, consumer interest is lower than when CSR communication focuses on environmental issues (Grimmer \& Bingham, 2013). Consumers are likely to pay more attention to CSR initiatives that directly affect them (i.e., environmental initiatives) than to those that aim to improve employees' well-being. For example, Singh et al. (2008) demonstrate that in both the UK and Spain, consumers have greater concern for companies' environmental behaviors than for companies' ethical behaviors, which include employee-based CSR initiatives. Thus, the effectiveness of rational arguments is higher for environmental issues (high involvement processing), whereas emotional appeals are more effective for employee-related CSR initiatives (low involvement processing).

\subsection{Hedonic versus utilitarian services}

Studies demonstrate that the effectiveness of marketing strategies for a particular service depends on service type (i.e., hedonic or utilitarian) (Hill et al., 2004; Stafford \& Day, 1995). Hedonic consumption reflects multi-sensory, fantasy, and emotive aspects of consumer experience, whereas utilitarian consumption focuses on functional consequences (Jiang \& Wang, 2006). Hedonic services provide consumers with hedonic values such as excitement and playfulness (e.g., restaurants and vacation resorts). Utilitarian services, in contrast, provide consumers with functional utilities or solve practical problems (e.g., car repairs and banking).

Research suggests that message appeal type must match product type for maximum effectiveness. In other words, a rational appeal is more effective for utilitarian products, whereas an emotional appeal is more effective for experiential products (Johar \& Sirgy, 1991). Support for this matching principle is inconclusive, however (Mortimer, 2008). Consumer behavior research shows that reliance on affective or cognitive information may vary by product type. Kempf (1999) argues that consumers evaluate utilitarian products using cognitive criteria, 
whereas consumers evaluate hedonic products on the basis of affective reactions. Consequently, the appeal type's suitability (i.e., rational appeal for utilitarian services and emotional appeal for hedonic services) might explain how service-based CSR initiatives affect consumers.

\subsection{Consumer reactions to CSR communication strategies}

Research shows that service companies enhance brand equity by increasing their commitment to CSR (Hoeffler \& Keller, 2002; Torres et al., 2012). Keller (1993) defines brand equity as the differential effect of brand knowledge on consumer response to the marketing of the brand. Brand awareness is the first step toward building brand equity (Hoeffler \& Keller, 2002). Perceived uniqueness of the brand, brand attitude, and an emotional connection with the target audience are additional requirements for brand equity (Berry, 2000). Studies also show that CSR attributions of the motives underlying a company's CSR initiatives affect consumers' brand perceptions (Du et al., 2010).

CSR awareness. Research demonstrates that CSR awareness induces positive attitudes and behavioral intentions (Brown \& Dacin, 1997). Effective CSR communication makes consumers aware of such initiatives; otherwise, they will purchase a similar product that does not have such attributes. Thus, marketing communications are important in raising CSR awareness among individuals who want to purchase products with CSR attributes (McWilliams \& Siegel, 2001).

Brand attitude and perceived uniqueness. To create brand equity, companies must ensure their brand has some strong, favorable, and unique brand associations (Keller, 1993). CSR studies suggest that social responsibility is "a distinct brand personality dimension" (Madrigal \& Bousch, 2008, p. 538). A brand personality dimension is "an enduring, differentiating characteristic that describes a brand's actions with respect to its obligation to the society at large, and the individuals living in that society" (p. 540).

Emotional responses. Berry (2000) reports that brands reflecting consumers' core values induce emotional bonding. An individual's emotions reflect his or her appraisals of something relevant to his or her well-being (Bagozzi et al., 1999). CSR research indicates that consumers are more likely to form an emotional attachment with brands that provide opportunities to do good (Sen \& Bhattacharya, 2001). Consequently, service brands that communicate socially responsible initiatives induce positive emotional responses and convey positive brand image.

CSR attributions refer to "causal reasoning consumers engage in when trying to understand a company's CSR activities" (Bhattarcharya \& Sen, 2004, p. 14). Attribution theory posits that consumers attempt to understand company motives behind marketing communications (Becker-Olsen et al., 2006). Thus, when a company communicates its CSR actions, consumers are likely to ponder the message and perceive the company's motive to be either self-serving (e.g., to increase profits and sales) or social (e.g., to support employees) (Becker-Olsen et al., 2006). Therefore, companies must ensure that consumers attribute CSR initiatives to motives reflecting genuine concern for society's welfare rather than profitability 
(Bigné et al., 2012). This study tests the following research hypotheses.

H1: When a service-based CSR initiative focuses on environmental issues, a rational appeal generates a higher level of CSR awareness (H1a), service brand attitude (H1b), perceived uniqueness (H1c), emotional responses (H1d), and CSR attributions with social motives (H1e) than an emotional appeal generates.

$\mathrm{H} 2$ : When a service-based CSR initiative focuses on employees, an emotional appeal generates a higher level of CSR awareness (H2a), service brand attitude (H2b), perceived uniqueness $(\mathrm{H} 2 \mathrm{c})$, emotional responses $(\mathrm{H} 2 \mathrm{~d})$, and CSR attributions with social motives (H2e) than a rational appeal generates.

\section{Research method}

The research tests hypotheses using a 2 (type of CSR-service based initiative) x 2 (emotional/rational message appeal) x 2 (hedonic/utilitarian service) between-subjects design (Table 1).

Table 1 here.

The sample comprised 181 faculty and administrative employees at a large state university in the USA. Such experiments commonly use university staff as participants (Gau et al., 2012). Random assignment placed subjects in one of eight experimental conditions. The sample comprised $63.1 \%$ women. Participants' ages ranged from 23 to 76 years (13\% younger than $30,29 \%$ between 31 and 40, 26\% between 41 and 50, 23\% between 51 and $60,4 \%$ older than 61).

Participants became aware of service-based CSR initiatives by evaluating website content (Appendix 1). Websites in the experiment contained stimuli from real websites portraying employee-based and environment-related CSR initiatives in two service contexts: restaurants (hedonic) and banks (utilitarian). Drawing on Strahilevitz and Myers' (1998) procedure, the experiment included a manipulation check to test for perceived difference between utilitarian (functional/non-functional; necessary/unnecessary; and practical/impractical) and hedonic (delightful/not delightful and enjoyable/unenjoyable) services. Emotional websites generated positive emotions and created warm feelings, thereby conveying subjective, evaluative properties. Rational websites were more direct and presented facts straightforwardly. Rational websites were objective and induced cognitive elaboration. A manipulation check building on Liu and Stout's (1987) three items of emotional/rational appeals (logical/emotional; objective/subjective; and factual/nonfactual) tested the effectiveness of these appeals. Measurement of all items took place on a seven-point scale.

To avoid potential confounding effects, all experimental website content used the same image (i.e., a color picture from a real-life website), in both emotional and rational conditions. Using a fictitious service company name (XYZ) controlled for preexisting knowledge and attitudes. Specifically, the subjects read the following description: "Imagine that there is a new company in town and you would like to use its services. This company, XYZ, is known for 
great service and consumer care. Before contacting the company, you visit the company's website" (showing the rational/emotional website version).

Measures from the literature provided the basis for dependent measures. Asking consumers their perceived level of awareness of the company's CSR initiatives $(1=$ not at all to 7 = very much) captured CSR awareness (Pomering \& Dolnicar, 2009). A three-item semantic differentiation scale from Berry (2000) (bad/good; not favorable/favorable; and negative/positive) measured attitude toward the company. A four-item, Likert-type scale (Keller, 1993 ) measured perceived uniqueness ( 1 = distinct from other brands of restaurants/banks; $2=$ very different from other restaurants/banks; 3 = really stands out from other restaurants/banks; and 4 = unique from other restaurants/banks). Two items (to what extent the website makes consumers feel happy/pleasant: $1=$ not at all to 7 = very strongly) measured emotional responses to the website (Mattila, 2000). A three-item semantic differentiation scale (profitmotivated/socially-motivated; self-interested/community-interested; and companyfocused/consumer-focused) measured CSR attribution (Becker et al., 2006).

Confirmatory factor analysis (CFA) analyzed the psychometric properties of these scales (Table 2). Scales yielded acceptable psychometric properties: factor loadings greater than 0.5 , composite reliability greater than 0.7 , and average variance extracted greater than 0.5 and greater than the squared correlation with any other construct (Anderson \& Gerbing, 1988; Fornell \& Larcker, 1981).

Table 2 here.

\section{Results}

\subsection{Manipulation checks}

As per expectations, consumers perceive rational stimuli to be more factual than emotional stimuli $(F=12.27, p<0.01)$. Similarly, consumers perceive emotional stimuli to be more emotional $(F=12.41, p<0.01)$, more subjective $(F=19.76, p<0.01)$, and less factual $(F=6.74, p<0.05)$ than rational stimuli. Finally, consumers perceive the utilitarian service (bank) to be more necessary $(F=18.72, p<0.01)$ than the hedonic service. Conversely, consumers perceive the hedonic service (restaurant) to be more delightful $(F=17.77, p<0.01)$ and enjoyable $(F=25.11, p<0.01)$ than the utilitarian service.

\section{2. $\quad$ Service-based CSR initiative, message appeals, and type of service \\ This study tests the research hypotheses using multivariate ANOVA (Table 3).} Table 3 here.

For CSR awareness, multivariate ANOVA detects a significant interaction in utilitarian services $(F=6.22, p<0.05)$ (Figure 1): rational appeals outperform emotional appeals in environment-related CSR initiatives, whereas emotional appeals outperform rational appeals in employee-based CSR initiatives. Results reveal no significant interaction effect in hedonic services. These results partially support hypotheses 1a and 2a. 
Figure 1 here.

For company attitudes and perceived uniqueness, ANOVA detects no interaction effects in hedonic or utilitarian services. This finding leads to rejecting hypotheses $1 \mathrm{~b}, 1 \mathrm{c}, 2 \mathrm{~b}$, and $2 \mathrm{c}$. For emotional responses, results reveal a significant interaction in utilitarian services $(F=3.07$, $p<0.10$ ) (Figure 2): rational appeals outperform emotional appeals in environment-related initiatives, whereas emotional appeals outperform rational appeals in employee-based CSR initiatives. Results reveal no significant interaction effects in hedonic services. Thus, results partially support hypotheses $1 \mathrm{~d}$ and $2 \mathrm{~d}$.

Figure 2 here.

For perceived CSR attribution, results show a significant interaction effect in utilitarian services $(F=7.62, p<0.01)$ (Figure 3$)$ and hedonic services $(F=3.53, p<0.10)$ (Figure 4$)$ : rational appeals outperform emotional appeals in environment-related initiatives, whereas emotional appeals outperform rational appeals in employee-based CSR initiatives. Thus, in both service types, when companies communicate environment-related CSR initiatives using rational appeals and employee-based initiatives using emotional appeals, consumers attribute company motivation to social motives. Thus, results support hypotheses $1 \mathrm{e}$ and $2 \mathrm{e}$.

Figure 3 here.

Figure 4 here.

\section{Discussion and conclusions}

Findings indicate that consumers' reactions to CSR depend on three factors: type of CSR stimuli (environment-related or employee-based), message appeal (rational or emotional), and type of service (hedonic or utilitarian). Rational appeals are more effective with environmental CSR initiatives, whereas emotional appeals are more effective with employee-based initiatives. This finding is consistent with findings in the literature, which show that communication appeal must match individuals' attitudes and processing styles (Dube et al., 1996).

When CSR attribution is an outcome variable, effects of message appeal matching are observable in both service contexts (hedonic and utilitarian). For brand equity, results show only an effect of rational appeals on environment-related CSR initiatives. Only if the rational message appeal refers to a utilitarian service does the appeal affect consumers' CSR awareness and emotional responses. Findings are consistent with those in the advertising literature, namely that consumers process information about utilitarian products by focusing on the message argument (Petty \& Cacioppo, 1984).

Findings have important implications for service companies that invest heavily in CSR. First, these companies must seek to match message type and appeal. Matching message type and appeal positively affects consumers' attributions of companies' CSR motives. Second, benefits of matching are even greater in utilitarian services than in hedonic services because benefits extend to CSR awareness and emotions. Previous research shows that a lack of consumer awareness is limiting companies' abilities to evaluate CSR as a strategic investment 
(Du et al., 2010; Pomering \& Dolnicar, 2009). Findings show that consumers' CSR awareness depends on the type of service, message appeal, and CSR initiative.

These findings raise important questions to address in future research. This study focuses on two types of CSR initiatives, but future research should examine message appeals' relative effectiveness for other CSR initiatives such as charitable donations and employee volunteering programs. In addition, because different consumers perceive CSR initiatives differently, future research should address how consumer commitment to the CSR initiative affects relationships between message appeal type, CSR type, service type, and consumer evaluations. This study considers only two service types. Therefore, future research should examine the robustness of these findings in other service segments using different empirical methods (e.g., fsQCA). Although studying employees is relevant, a larger sample containing non-employees would help generalize findings. Future research should use real-life stimuli to account for pre-existing brand attitudes. Examining behavioral consequences of CSR initiatives would also be beneficial. Research should explore linkages between message appeal, CSR content, and consumer engagement. Finally, scholars call for a cross-cultural investigation of consumer reactions to CSR (Beckmann et al., 2006). 


\section{References}

Aguinis, H., \& Glavas, A. (2012). What we know and don't know about corporate social responsibility: A review and research agenda. Journal of Management, 38(4), 932-968.

Albers-Miller, N. D., \& Stafford, M. R. (1999). International services advertising: An examination of variation in appeal use for experiential and utilitarian services. Journal of Services Marketing, 13(4/5), 390-406.

Anderson, J. C., \& Gerbing, D. W. (1988). Structural equation modeling in practice: A review and recommended two-step approach. Psychological Bulletin, 103(3), 411-423.

Argyriou, E., Kitchen, P. J., \& Melewar, T. C. (2006). The relationship between corporate websites and brand equity: A conceptual framework and research agenda. International Journal of Market Research, 48(5), 575-599.

Bagozzi, R. P., Gopinath, M., \& Nyer, P. U. (1999). The role of emotions in marketing. Journal of the Academy of Marketing Science, 27(2), 184-206.

Bartl, C., Gouthier, M. H. J., \& Lenker, M. (2013). Delighting consumers click by click: Antecedents and effects of delight online. Journal of Service Research, 16(3), 386-399.

Becker-Olsen, K. L., Cudmore, B. A., \& Hill, R. P. (2006). The impact of perceived corporate social responsibility on consumer behavior. Journal of Business Research, 59(1), 46-53.

Beckmann, S. C. (2007). Consumers and corporate social responsibility: Matching the unmatchable? Australasian Marketing Journal, 5(1), 27-36.

Beckmann, S. C., Morsing, M., \& Reisch, L. (2006). Strategic CSR communication: An emerging field. In M. Morsing \& S. C. Beckmann (Eds.), Strategic CSR communication (pp. 11-36). Copenhagen: DJOEF Publishing.

Berry, L. L. (2000). Cultivating service brand equity. Journal of the Academy of Marketing Science, 28(1), 128-137.

Bhattacharya, C. B., \& Sen, S. (2004). Doing better at doing good: When, why, and how consumers respond to corporate social initiatives. California Management Review, 47(1), 9-24.

Bigné, E., Currás-Pérez, R., \& Aldás-Manzano, J. (2012). Dual nature of cause-brand fit: Influence on corporate social responsibility consumer perception. European Journal of Marketing, 46(3/4), 575-594.

Brown, T. J., \& Dacin, P. A. (1997). The company and the product: Corporate associations and consumer product responses. Journal of Marketing, 61(1), 68-84.

Campbell, J. L. (2007). Why would corporations behave in socially responsible ways? An institutional theory of corporate social responsibility. Academy of Management Review, 32(3), 946-967.

Du, S., Bhattacharya, C. B., \& Sen, S. (2010). Maximizing business returns to Corporate Social Responsibility (CSR): The role of CSR communication. International Journal of Management Reviews, 12(1), 8-19.

Dube, L., Chattopadhyay, A., \& Letarte, A. (1996). Should advertising appeals match the basis 
of consumer's attitudes? Journal of Advertising Research, 36(6), 82-89.

Fornell, C., \& Larcker, D. F. (1981). Evaluating structural equation models with unobservable variables and measurement error. Journal of Marketing Research, 18(1), 39-50.

Gau, R., Jae, H., \& Viswanathan, M. (2012). Studying low-literate consumers through experimental methods: Implications for subsistence marketplaces. Journal of Business Research, 65(12), 1683-1691.

Grimmer, M., \& Bingham, T. (2013). Company environmental performance and consumer purchase intentions. Journal of Business Research, 66(10), 1945-1953.

Hill, D. J., Blodgett, J., Baer, R., \& Wakefield, K. (2004). An investigation of visualization and documentation strategies in services advertising. Journal of Service Research, 7(2), $155-166$.

Hoeffler, S., \& Keller, K. (2002). Building brand equity through corporate societal marketing. Journal of Public Policy \& Marketing, 21(1), 78-89.

Hur, W. M., Kim, H., \& Woo, J. (2014). How CSR leads to corporate brand equity: Mediating mechanisms of corporate brand credibility and reputation. Journal of Business Ethics, 125(1), 75-86.

Jiang, Y., \& Wang, C. L. (2006). The impact of affect on service quality and satisfaction: The moderation of service contexts. Journal of Services Marketing, 20(4), 211-218.

Johar, J. S., \& Sirgy, M. J. (1991). Value-expressive versus utilitarian advertising appeals: When and why to use which appeal. Journal of Advertising, 20(3), 23-33.

Keller, K. L. (1993). Conceptualizing, measuring, and managing customer-based brand equity. Journal of Marketing, 57(1), 1-22.

Kempf, D. S. (1999). Attitude formation from product trial: Distinct roles of cognition and affect for hedonic and functional products. Psychology \& Marketing, 16(1), 35-50.

Korschun, D., Bhattacharya, C. B., \& Swain, S. D. (2014). Corporate social responsibility, customer orientation, and the job performance of frontline employees. Journal of Marketing, 78(3), 20-37.

Liu, S. S., \& Stout, P. A. (1987). Effects of message modality and appeal on advertising acceptance. Psychology \& Marketing, 4(3), 167-187.

Madrigal, R., \& Bousch, D. M. (2008). Social responsibility as a unique dimension of brand personality and consumers' willingness to pay. Psychology \& Marketing, 25(6), 538564.

Mattila, A. S. (2000). The role of narratives in the advertising of experiential services. Journal of Service Research, 3(1), 35-45.

McWilliams, A., \& Siegel, D. (2001). Corporate social responsibility: A theory of the firm perspective. The Academy of Management Review, 26(1), 117-127.

Mortimer, K. (2008). Identifying the components of effective service advertisements. Journal of Services Marketing, 22(2), 104-113.

Öberseder, M., Schlegelmilch, B. B., \& Murphy, P. E. (2013). CSR practices and consumer 
perceptions. Journal of Business Research, 66(10), 1839-1851.

Page, T. J., Thorson, E., \& Heide, M. P. (1990). The memory impact of commercials varying in emotional appeal and product involvement. In S. J. Agres, J. A. Edell, \& T. M. Dubitsky (Eds.), Emotion in Advertising (pp. 255-268). New York: Quorum Books.

Petty, R. E., \& Cacioppo, J. T. (1984). The effects of involvement on responses to argument quantity and quality: Central and peripherals routes to persuasion. Journal of Personality and Social Psychology, 48(1), 69-81.

Pomering, A., \& Dolnicar, S. (2009). Assessing the prerequisite of successful CSR implementation: Are consumers aware of CSR initiatives? Journal of Business Ethics, 85(2), 285-301.

Sen, S., \& Bhattacharya, C. (2001). Does doing good always lead to doing better? Consumer reactions to corporate social responsibility. Journal of Marketing Research, 38(2), 225243.

Sen, S., Bhattacharya, C. B., \& Korschun, D. (2006). The role of corporate social responsibility in strengthening multiple stakeholder relationships: A field experiment. Journal of the Academy of Marketing Science, 34(2), 158-166.

Singh, J., García de los Salmones, M. M., \& Rodríguez del Bosque, I. (2008). Understanding corporate social responsibility and product perceptions in consumer markets: A crosscultural evaluation. Journal of Business Ethics, 80(3), 597-611.

Singh, S. N., \& Dalal, N. P. (1999). Web home pages as advertisements. Communications of the $A C M, 42(8), 91-98$.

Stafford, M. R. (2005). International services advertising (ISA): Defining the domain and reviewing the literature. Journal of Advertising, 34(1), 65-86.

Stafford, M. R., \& Day, E. (1995). Retail services advertising: The effects of appeal, medium, and service. Journal of Advertising, 24(1), 57-71.

Strahilevitz, M. A., \& Myers, J. G. (1998). Donations to charity as purchase incentives: How well they work may depend on what you are trying to sell. Journal of Consumer Research, 24(4), 434-446.

Torres, A., Bijmolt, T. H. A., Tribó, J. A., \& Verhoef, P. (2012). Generating global brand equity through corporate social responsibility to key stakeholders. International Journal of Research in Marketing, 29(1), 13-24.

Um, N. H. (2008). Revisit elaboration likelihood model: How advertising appeals work on attitudinal and behavioral brand loyalty centering around low vs. high involvement product. European Journal of Social Sciences, 7(1), 126-139.

Vaaland, T. I., Heide, M., \& Grønhaug, K. (2008). Corporate social responsibility: Investigating theory and research in the marketing context. European Journal of Marketing, 42(9/10), 927-953.

Zeithaml, V. A., Bitner, M. J., \& Gremler, D. D. (2013). Services marketing. Integrating customer focus across the firm ( $6^{\text {th }}$ edition). New York: McGraw-Hill. 
Table 1. Between-subjects factor sample sizes

\begin{tabular}{llll}
\hline Service type & Appeal & Stimulus & $N$ \\
\hline \multirow{2}{*}{ Hedonic (restaurant) } & Rational & Environment & 28 \\
& & Employee & 27 \\
& Emotional & Environment & 24 \\
Utilitarian (bank) & Rational & Employee & 21 \\
& & Environment & 17 \\
& Emotional & Employee & 20 \\
\hline
\end{tabular}


Table 2. Confirmatory factor analysis results $(n=181)$

\begin{tabular}{|c|c|c|c|c|c|c|c|c|c|c|}
\hline Factor & Mean & SD & Indicator & Loading & $\begin{array}{l}\text { Robust } \\
\text { value }\end{array}$ & $t$ & LA & $\mathrm{CA}$ & $\mathrm{CR}$ & AVE \\
\hline Awareness & 4.79 & 1.31 & AWA0 & -- & -- & & -- & -- & -- & -- \\
\hline \multirow[t]{3}{*}{ Attitude } & 4.48 & 1.39 & ATS1 & $0.85^{a}$ & 12.59 & & 0.91 & 0.93 & 0.94 & 0.83 \\
\hline & 4.52 & 1.43 & ATS2 & $0.95^{\mathrm{a}}$ & 12.27 & & & & & \\
\hline & 4.57 & 1.39 & ATS3 & $0.93^{\mathrm{a}}$ & 16.02 & & & & & \\
\hline \multirow[t]{4}{*}{ Uniqueness } & 4.24 & 1.59 & UNIQ1 & $0.85^{\mathrm{a}}$ & 15.22 & & 0.86 & 0.92 & 0.92 & 0.72 \\
\hline & 4.02 & 1.66 & UNIQ2 & $0.85^{\mathrm{a}}$ & 15.07 & & & & & \\
\hline & 3.97 & 1.55 & UNIQ3 & $0.86^{\mathrm{a}}$ & 12.28 & & & & & \\
\hline & 3.95 & 1.65 & UNIQ4 & $0.88^{\mathrm{a}}$ & 16.52 & & & & & \\
\hline \multirow[t]{2}{*}{ Emotion } & 3.95 & 1.85 & EMO1 & $0.87^{\mathrm{a}}$ & 17.87 & & 0.93 & 0.91 & 0.92 & 0.86 \\
\hline & 3.95 & 1.67 & EMO2 & $0.98^{\mathrm{a}}$ & 21.68 & & & & & \\
\hline \multirow[t]{3}{*}{ Attribution } & 4.23 & 1.69 & ATR1 & $0.94^{\mathrm{a}}$ & 18.10 & & 0.76 & 0.79 & 0.81 & 0.60 \\
\hline & 3.83 & 1.53 & ATR2 & $0.58^{\mathrm{a}}$ & 6.58 & & & & & \\
\hline & 4.31 & 1.55 & ATR3 & $0.76^{\mathrm{a}}$ & 11.27 & & & & & \\
\hline
\end{tabular}

Model fit: S-B ${ }^{2}(d . f .=56)=75.42(p=0.04) ; \mathrm{CFI}=0.95 ; \mathrm{TLI}=0.99 ; \mathrm{RMSEA}=0.04 ; \mathrm{CI} 90 \%$ [0.008-0.068]

Note $:$ LA $=$ Loadings average $; \mathrm{CA}=$ Cronbach's alpha; $\mathrm{CR}=$ Composite Reliability; $\mathrm{AVE}=$ Average Variance Extracted

${ }^{\mathrm{a}} \mathrm{p}<0.01 ;{ }^{\mathrm{b}} \mathrm{p}<0.05$ 
Table 3. Multivariate ANOVA results

\begin{tabular}{lllllll}
\hline & \multicolumn{3}{l}{ Hedonic service: restaurant $(n=100)$} & \multicolumn{3}{l}{ Utilitarian service: bank $(n=81)$} \\
\cline { 2 - 7 } & $\begin{array}{l}\text { Appeal } \\
(\mathrm{A})\end{array}$ & $\begin{array}{l}\text { Stimulus } \\
(\mathrm{S})\end{array}$ & $\begin{array}{l}\text { Interaction } \\
(\mathrm{AxS})\end{array}$ & $\begin{array}{l}\text { Appeal } \\
(\mathrm{A})\end{array}$ & $\begin{array}{l}\text { Stimulus } \\
(\mathrm{S})\end{array}$ & $\begin{array}{l}\text { Interaction } \\
(\mathrm{AxS})\end{array}$ \\
\hline Awareness & 0.16 & 0.01 & 1.57 & 0.87 & 1.60 & $6.22^{\mathrm{b}}$ \\
& $(0.69)$ & $(0.95)$ & $(0.21)$ & $(0.35)$ & $(0.21)$ & $(0.02)$ \\
Attitude & 0.35 & 0.11 & 0.84 & 2.19 & 1.14 & 0.50 \\
& $(0.56)$ & $(0.74)$ & $(0.36)$ & $(0.14)$ & $(0.29)$ & $(0.48)$ \\
Uniqueness & 0.42 & 0.29 & 0.43 & 0.01 & $10.2^{\mathrm{a}}$ & 1.94 \\
& $(0.52)$ & $(0.59)$ & $(0.51)$ & $(0.95)$ & $(0.00)$ & $(0.17)$ \\
Emotion & 0.21 & 2.26 & 2.46 & 0.15 & $3.72^{\mathrm{c}}$ & $3.07^{\mathrm{c}}$ \\
& $(0.65)$ & $(0.14)$ & $(0.12)$ & $(0.70)$ & $(0.05)$ & $(0.08)$ \\
Attribution & 0.07 & $5.51^{\mathrm{b}}$ & $3.53^{\mathrm{c}}$ & 1.95 & 0.11 & $7.62^{\mathrm{a}}$ \\
& $(0.80)$ & $(0.02)$ & $(0.06)$ & $(0.17)$ & $(0.75)$ & $(0.00)$ \\
\hline
\end{tabular}

Note: $F$-value $($ d.f. $=1), p$-values in parentheses. Appeal (rational vs. emotional), Stimulus (environment vs. employee-based).

${ }^{\mathrm{a}} p<0.01,{ }^{\mathrm{b}} p<0.05,{ }^{\mathrm{c}} p<0.10$ 
Figure 1. Effect of CSR stimuli and message appeal on consumer CSR awareness for utilitarian services (banks)

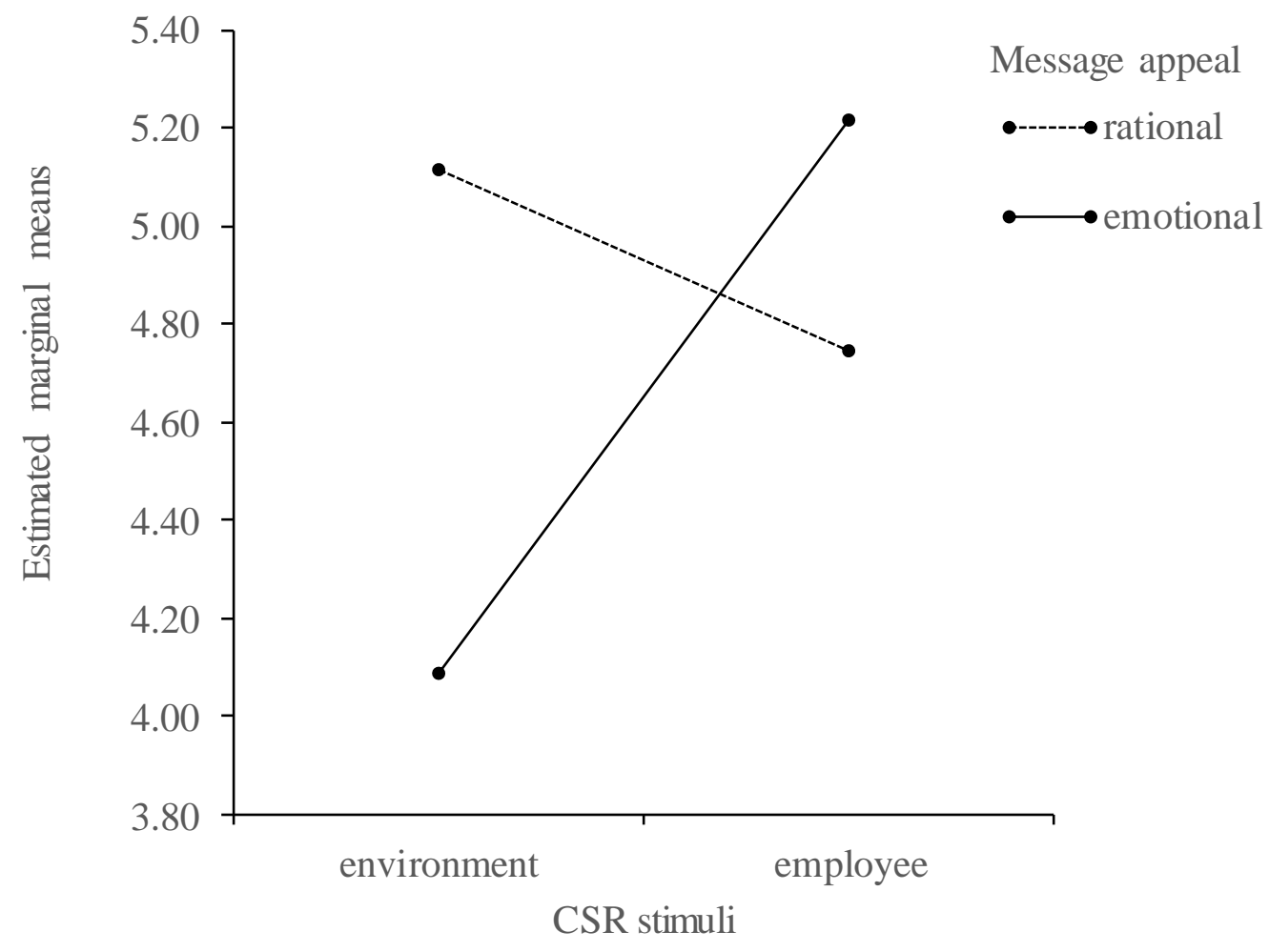


Figure 2. Effect of CSR stimuli and message appeal on consumer emotional responses for utilitarian services (banks)

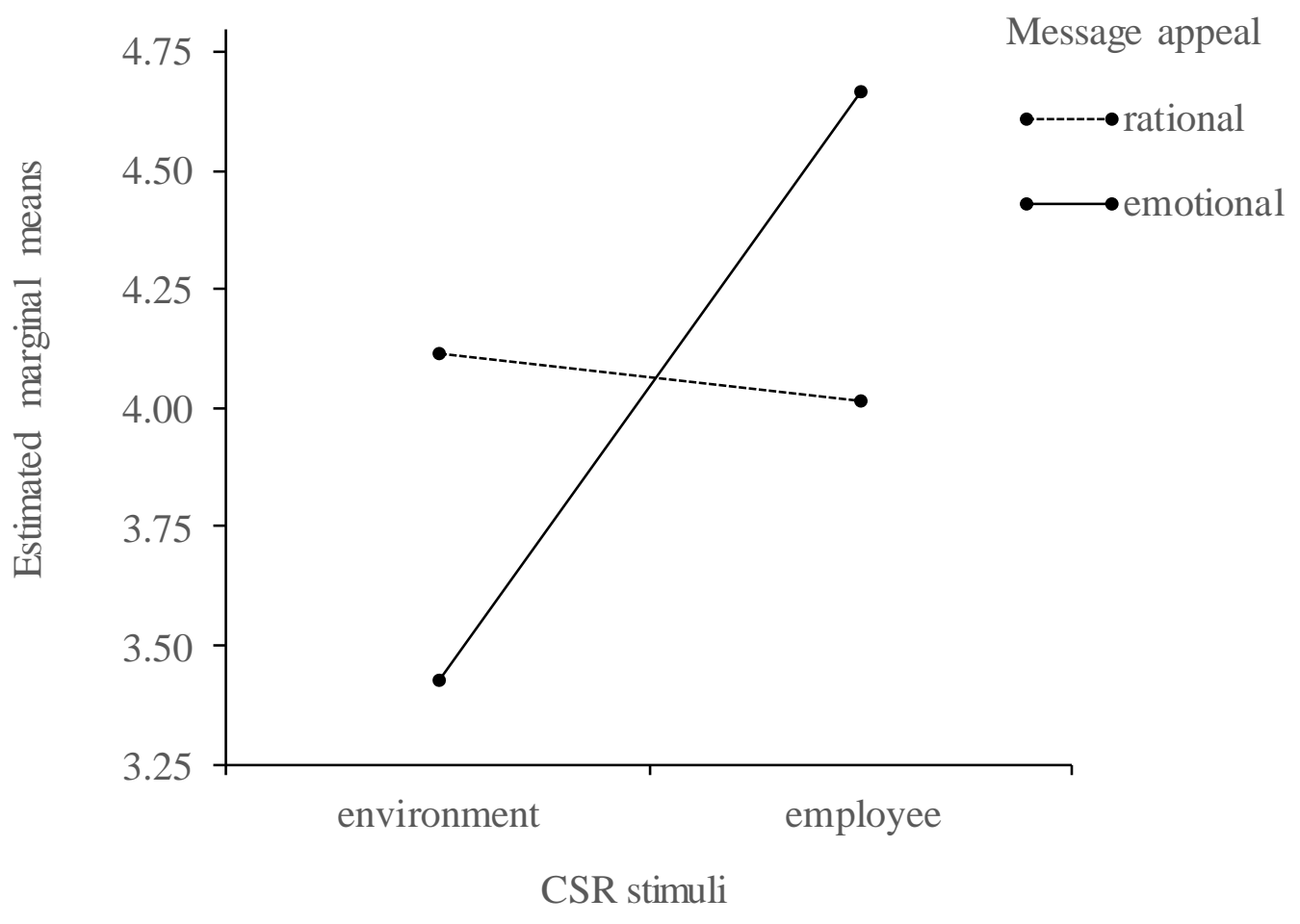


Figure 3. Effect of CSR stimuli and message appeal on consumer CSR attribution responses for utilitarian services (banks)

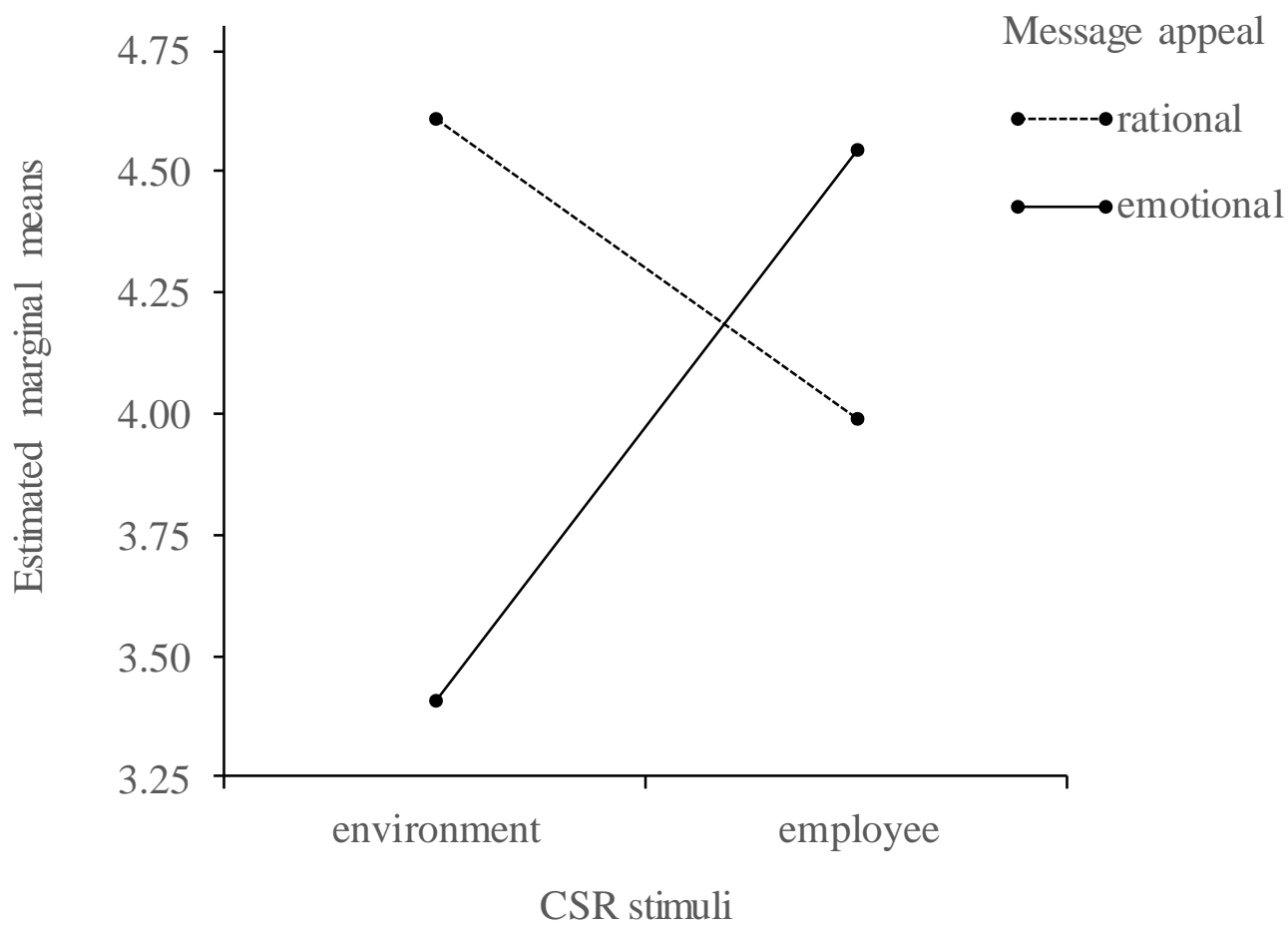


Figure 4. Effect of CSR stimuli and message appeal on consumer CSR attribution responses for hedonic services (restaurants)

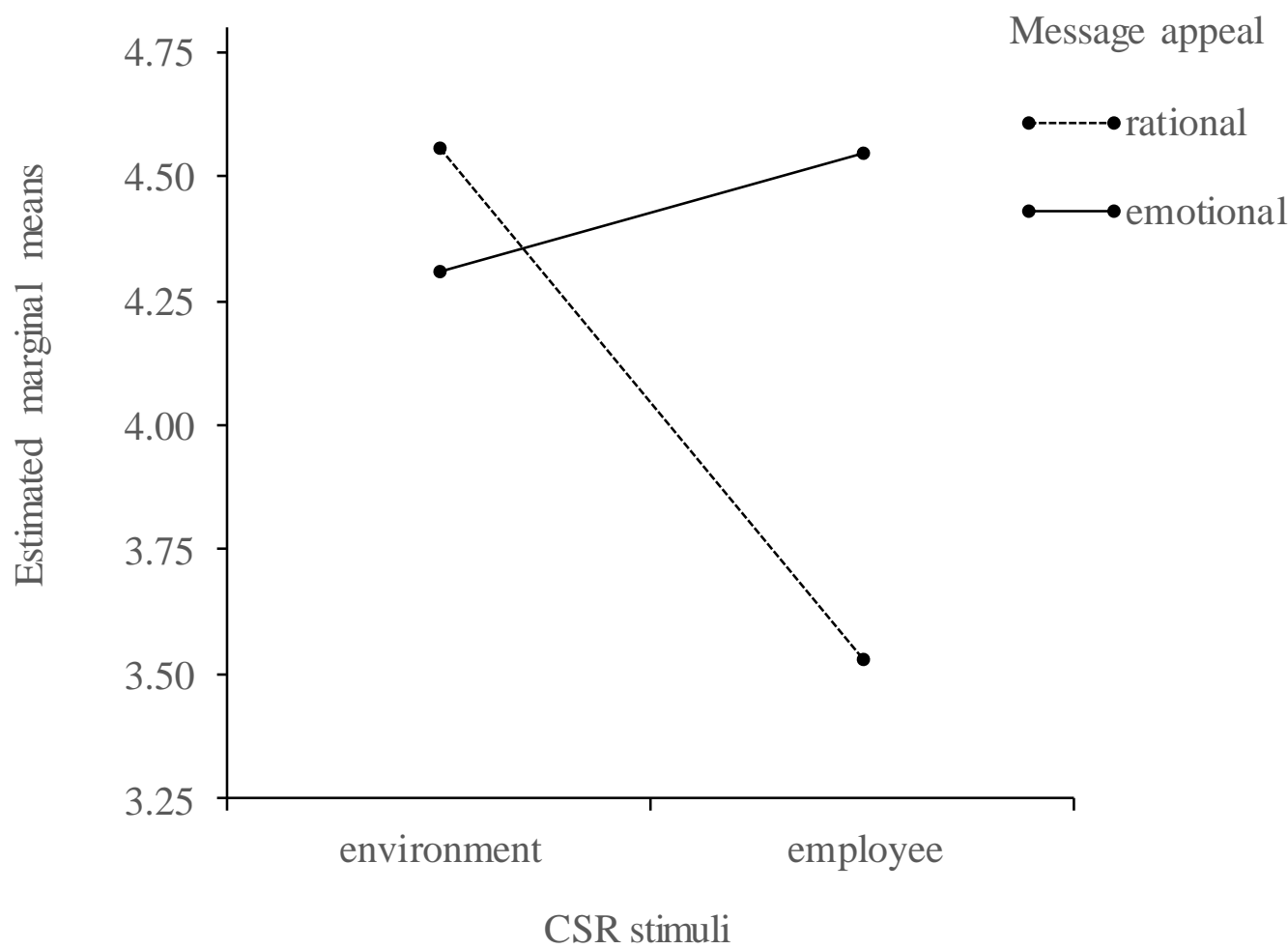


Appendix 1. Website stimuli evaluated by participants in the experiment

Website A (employee, rational)

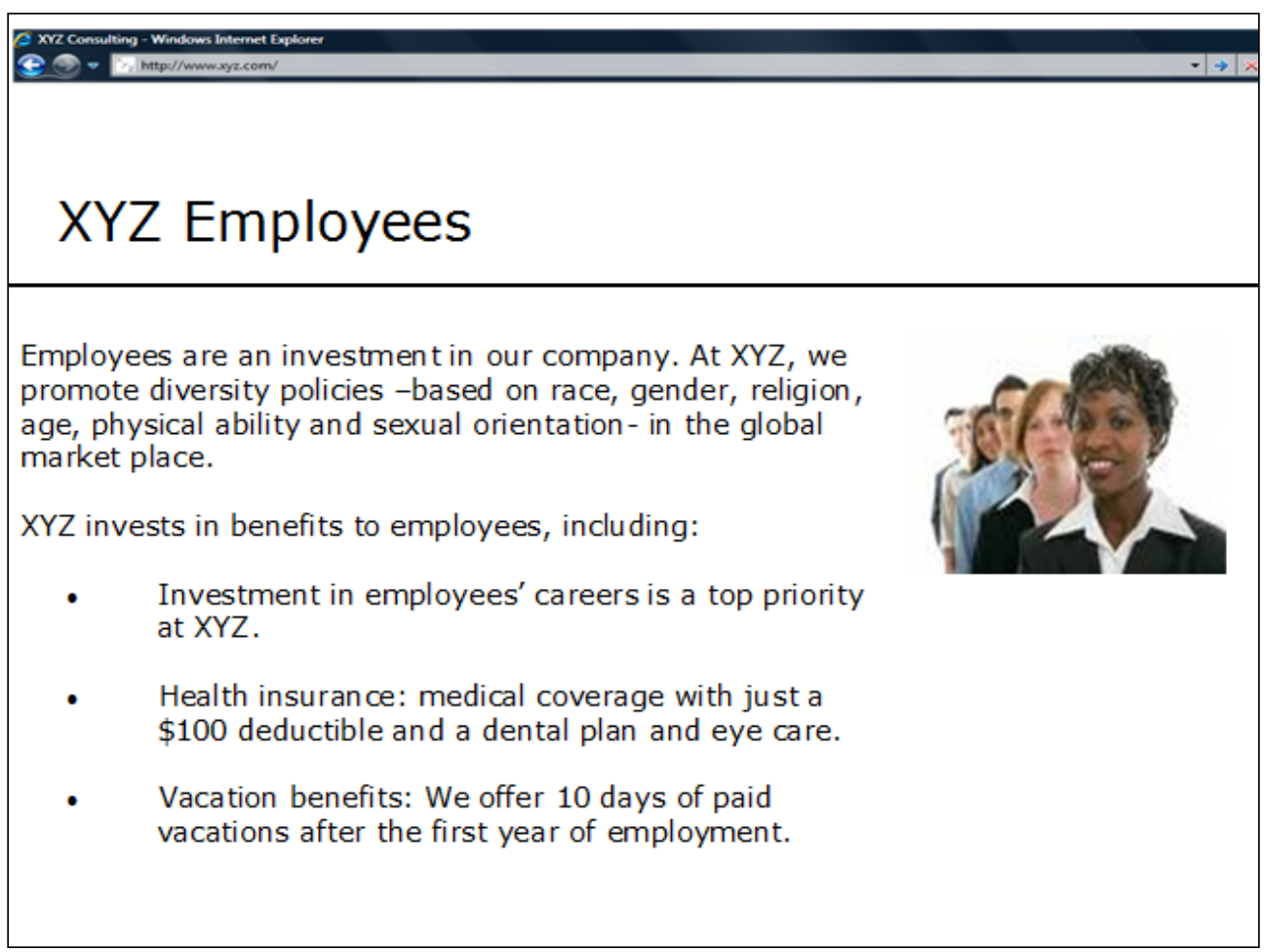

Website B (employee, emotional)

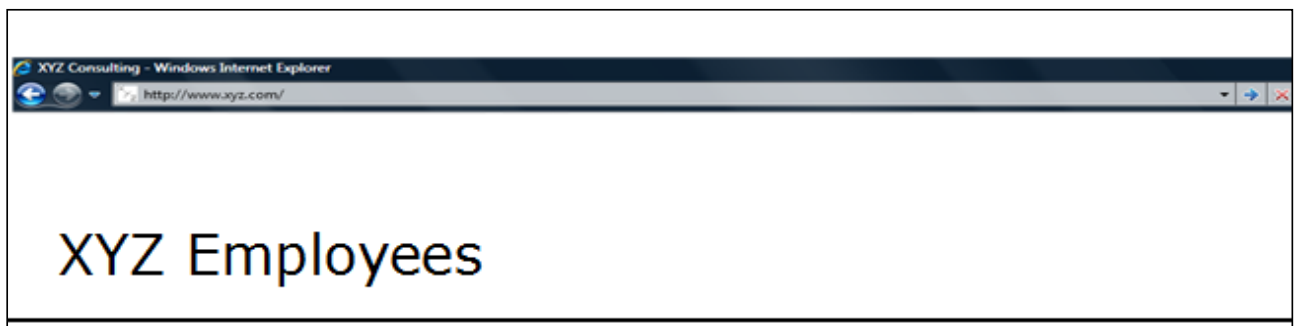

Above all, we are about people. Our tradition of inclusion drives our organization. We celebrate the dimensions of diversity of our employees based on race, gender, religion, age, physical ability and sexual orientation.

$\mathrm{XYZ}$ nu rtures employees as family members:

- We give our employees the freedom to develop

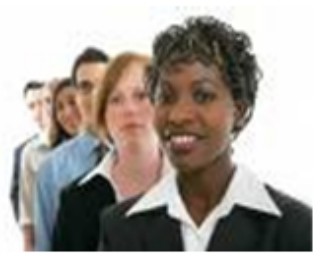
su ccess skills at XYZ.

- We take care of our employees and support their health needs.

- We recognize the importance of work/family balance and offer a number of programs designed to assist our employees in finding fulfillment and enjoyment in both their personal lives and their careers. 
Website C (environment, rational)

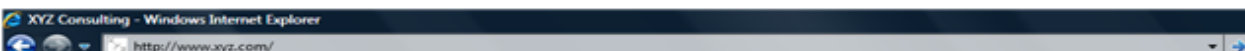

\section{XYZ Environment}

XYZ develops a set of principles to inform customers, employees and others partners to effectively work to ensure protection of ecosystems.

Ou r initiatives focus on sustainability practices to maintain natural resources in the long-term:

Conserving natural resources by recycling and reusing materials.

Designing stores/offices to be energy efficient using technologically advanced energy management systems.

Website D (environment, emotional)

\section{XYZ Environment}

Just like you, we love our environment and want our children to enjoy it for years to come.

$\mathrm{XYZ}$ encourages customers, employees and others partners to take a thoughtful approach toward the environment.

We reviewed company operations, which helped set the cou rse for many ongoing environmental initiatives recycling and reusing materials, environmentally friendly stores/offices-with benefits to your family and future generations' well-being. 